\title{
Collaborative Forest Management in Nepal: Stepping towards managing productive forests of Terai with social inclusion
}

- Dhananjaya Paudyal

\section{Introduction}

The Government of Nepal has been making several efforts to manage the forests of the lowlands of Nepal in a scientific manner for economic growth of the nation as well as for the benefit of the local people. In the past, various such attempts had not been successful due to the centralised institutional structure of the forest management administration (Ebregt et al., 2007). After late seventies, it was realised that forests of Nepal could only be saved through the active participation of forest users. Then, participatory forest management modalities like community forestry and pro-poor leasehold forestry have been implemented in Nepal. Community Forestry Programme has gained a good momentum especially in hills through which more than a million hectares of degraded natural forests are restored and managed with participation of local forest users.

In Terai, situation is quite different. Large blocks of productive national forests are located in the North, while the majority of the population lives in the South (in some cases up to $45 \mathrm{~km}$ far from the national forests). Latest effort of the government in order to manage these productive forests was implementing Operational Forest Management Plans (OFMPs). Although, OFMPs were sound technically, it could not be implemented due to lack of acceptance and participation of the local people. Considering these facts, Government of Nepal felt need of policy revision as prescribed by the Master Plan (1989), mainly to manage the productive block forests in Terai region.

The Revised Forest Policy, 2000 has an innovative concept for managing the "Government Managed" block forests of Terai region in a collaborative mode of management involving different stakeholders for management and benefit sharing (MFSC, 2000). Collaborative Forest Management (CFM) addresses more Terai specific issues such as inclusion of distant users (Ebregt, et al., 2007). Although the term CFM as forest management modality was already applied elsewhere in the world, the interpretation of what it entailed is everywhere different however. In Nepalese context, CFM is an approach of sustainable forest management in collaboration with the local people to achieve multiple benefits, maintaining ecological balance, generating economic returns and improving livelihood from the government managed forests (CFM WG, 2003). This approach tries to bring together the different stakeholders considering the spatial configuration of the Terai (close and distant users are often from a different ethnic background), while using the learning from the experiences of Community Forestry and different participatory management modalities operational in Nepal and other countries.

The main objective of CFM approach is to develop sustainable forest management in order to 1) fulfil the needs for forest products, 2) help in poverty reduction by creating employment, 3) maintain and enhance biodiversity, and 4) increase national and local income through active management of the Terai and Inner Terai forests. In December 2004, the Ministry of Forest and Soil Conservation (MFSC) approved 3 pilot CFM Schemes one in each Bara, Parsa and Rautahat Districts. Other CFM schemes are in the process of preparation (Annex 1).

The Biodiversity Sector Program for Siwaliks and Terai (BISEP-ST) is a program of Ministry of Forest and Soil Conservation (MFSC) supported by the Netherlands through Netherlands Development Organisation (SNV-Nepal). This programme is being implemented in eight Terai and inner Terai districts of the Central Development Region of Nepal (Chitwan, Makwanpur, Parsa, Bara, Rautahat, Sarlahi, Mahottari and Dhanusha) through forestry sector district level line agencies and Non-Governmental Organisations (NGOs). The program aims to fulfil the goal: "Forestry sector contributing to poverty reduction through sustainable

${ }^{*}$ Forest Management Officer, BISEP-ST, Regional Support Unit, $\bar{H}$ etaùda 
resource management". To fulfil this goal two purposes are formulated: 1) Promoting good forest governance as a means of enhancing forest and biodiversity conservation, and 2) Enhancing livelihoods opportunities for poor, forest dependent people in the Programme districts. BISEP-ST has been supporting implementation of various forestry related programmes including various participatory forest management models like Community Forestry, Collaborative Forest Management, Pro-poor leasehold forestry, Private forestry and Public land forestry.

Based on learning from CFM implementation, some of its strengths are observed. At the mean time some issues and challenges are also emerging which should be properly addressed for the successful implementation of the programme. This paper highlights basic features, roles of stakeholders, strengths and weaknesses of CFM implemented under BISEP-ST and presents potential strategies as way forward for its improvement.

\section{Key features of CFM}

CFM is one of the forms of participatory forest management models, its salient features are:

a) CFM is applied on productive forests of Terai/Inner Terai regions (as per Forest Act 2049, it is applied on "Government Managed Forests").

b) District Forest Coordination Committee (DFCC), formed from the representatives of forestry sector stakeholders in the district, decides whether CFM or other forest management modalities are to be implemented in a particular forest area in the district. This is also indicated in District Forestry Sector Plans (DFSP) which have been so far prepared and approved by the respective DFCC.

c) In CFM implementation, collaboration is made among forest users (both close and distant), local and central government.

d) Forest Management is based on approved CFM Schemes where intensive management is prescribed under the principles of Sustainable Forest Management.

e) Institutional Structure of CFM comprises CFM Group, committee, sub-committees and implementation unit. CFM Group is the representative apex body of forest users which is formed from ward representatives (including women, dalit and janajati) selected by ward level forest users who are included in the social unit of CFM; VDC/Municipality and DDC representatives, NGOs and line agencies representatives including DFO staffs.

f) CFM Group assembly selects CFM committee and delegates necessary power to it such as decision making in forest management, institutional strengthening, forest products sales depot management and livelihood activities for identified poor households. Sub-Committees are formed by the committee to accomplish certain tasks like depot management, forest protection, monitoring, etc. Implementation Unit implements the decision of CFM Group/Committee.

g) Revenue sharing mechanism (as per CFM guideline) is such that $75 \%$ of the revenue collected from the sale of forest products goes to the central treasury while $25 \%$ remains with the CFM group and local government. In addition to forest management, CFM fund can be allocated for various income generating activities for poor, women groups, dalit and janajati.

h) Forest management and forest products distribution require large number of manpower like for silvicultural operations, harvesting, transportation, saw milling, sales depot management, etc. Therefore, it has great potential to use local labour and thus creates employment opportunities. For example, if three approved schemes are implemented as per approved CFM Scheme, 348030 man days of local labour will be employed within five years for forest management operations only.

i) CFM has also a great potential for exploring indigenous knowledge, bio-prospecting, association among artisans, handicrafts making and cottage industry development.

\section{Roles of forest users, collaborators and other stakeholders}

Users of CFM are both close and distant users. There are some distinct roles and benefit sharing mechanism between close and distant users. 
Close users, as they reside close to the forest (living up to $5 \mathrm{~km}$ far from forest are regarded as close users), they involve on forest protection activities like regular patrolling in and around the forest. They also participate actively on forest management activities like cleaning, thinning, tending, felling, plantation, etc as per approved schemes. They are also employed as forest labourer. Thus, close users get relatively more benefits from forest as compared to distant users. They can collect grass, fodder, fuel wood, small wood, medicines and other NTFPs, poles and timber from forest regularly as per group decision. In addition, identified poor households as close users are grouped and allocated some patch of forest fringes for income generating activities. For this, leasing arrangement is made between CFM Committee and these groups. Close users have equal right in decision making as compared to distant users.

Roles of distant users on forest protection and management are equally important as compared to close users. Distant users can control smuggling of timber and other forest products which are transported through their settlements. They can confiscate those forest products transported illegally through patrolling on potential smuggling routes and also support arresting the persons involved on it. Their role on decision making is important which creates ownership on forest management. They can contribute forest protection providing cash or kind as per decision made on general assembly. Likewise, distant users have given priority to participate on private and public land forestry development activities. As majority of forest users in CFM are distant users, the number of forest products sales depots established are more for them as compared to close users. They have equal access and use rights to the forest and decision making role like close users. As they live far from the forest, it is obvious that they can not to collect forest products from forest as equally as close users.

Role and responsibilities of major stakeholders of CFM are presented in Annex 2.

\section{$\underline{\text { Results }}$}

Collaborative Forest Management is a new practice in Nepal. It has been conceptualised after the approval of Revised Forest Policy 2000 and implemented after the approval of pilot schemes in 2004. Very short experience of implementing these schemes shows that it is successful in including close and distant users (including women and poor, Madhesi, Janajati, excluded castes like dalit and minority groups) not only in forest management, but also in several income generation activities in order to improve their livelihood. Benefit sharing is taking place between CFM Group and government. Forest products sales depots are established addressing needs of close and distant users. The revenues raised from the CFM Scheme implementation can be mobilized for forest management and several socioeconomic development activities. Learning from implementation of the schemes show the following major strengths:

Group fund raised: income from sale of forest products as per CFM Scheme, confiscated logs, penalty, fee as entry permission to forest, benefit from firewood depot management and fund provided by the programme and other donors are the major source of income of CFM Group.

Income generating activities initiated: part of the income is allocated for various income generating activities. These types of activities are focussed on poor households, dalit and women living close and far from the forests. For this, poor/landless households are identified and formed into groups. The major such activities include pig/goat farming, production and sale of handicrafts, incense, bio-briquette, NTFPs cultivation and enterprise development (eg. leaf plate), sewing/cutting, bee keeping, etc.

Women participation and empowerment: women and disadvantaged groups are participated in forest protection and management. Several ward and hamlet level women and disadvantaged groups are participated on forest protection activities. For example, in Halkhoria CFM (Bara), there are several VDC level women sub-committees for forest protection consisting 7-9 members per committee. In each CFM Group, a woman and a 
man is employed as CFM motivator.

Forest products distribution: forest is opened for users generally once in a week to collect fallen twigs, firewood and fodder. In Halkhoria CFM, about 85000 quintal firewood has been collected by users from forest. A total of 12 forest products sales depots are established in Bara, Parsa and Rautahat districts. In Halkhoria CFM, Bara forest products sales depots are established in 4 places for sale of firewood that purchased from District Forest Product Board supplied to CFM Users. Up to April 2007, 18 chatta ( 1 chatta $=20^{\prime} \times 5^{\prime}$ x 5' stack) confiscated firewood and about $6000 \mathrm{cft}$ timber (confiscated, fallen and uprooted collection from CFM) has sold to users. Likewise in Sabaiya CFM, Parsa, about $26151 \mathrm{cft}$ of timber and 55 chatta fuelwood collected as per approved CFM scheme and sold. Sales depot are established focusing distant users but some depots are established in order to benefit close users as well.

Private and public land forestry: private and public land forestry activities are implemented in 6 Terai districts (Bara, Parsa, Rautahat, Sarlahi, Mahottari, Dhanusha) covering 55 VDCs on cluster approach. Twelve local NGOs are involved (in twelve clusters, 2 cluster in a district at start). In public land forestry, public lands under VDCs and other public institutions available for lease are identified and allocated to poor groups for practicing public land (agro-)forestry. By public land forestry, 98 public land forestry groups consisting 850 households are managing 80 ha of public land by 2007.

Likewise, private forestry is implemented in the same clusters as public land forestry. By private forestry programme, 132 private forestry groups consisting 2100 households are managing 333 ha of private land as private (agro-) forestry. Private and public land forestry activities are implemented focusing distant users of CFM. For this, 15-25 households living in a locality are formed a private forestry group and 10-15 poor households grouped as public land forestry group.

Leasehold forestry in CFM: Forest fringe areas close to the settlements are allocated for income generating activities like NTFPs cultivation under trees. For this activity, identified poor households are grouped and land allocated to these groups with some form of agreement between the groups of identified poor households and CFM Committee.

Ownership: from the results so far mentioned, ownership is also increased to close and distant users.

\section{Areas of improvement}

Based on learning so far, there are some areas of improvement in CFM, which are indicated below:

$\S \quad$ Providing livelihood alternatives and creating employment opportunities for forest dependent poor people such as for large number of firewood collectors/sellers.

$\S \quad$ Empowering and mainstreaming forest dependent people (including women, dalit, janajati and disadvantaged groups) and distant users.

$\S \quad$ Exploring indigenous knowledge and skills in forestry related activities.

$\S \quad$ Provision of subsidised forest products like timber and firewood for poor households.

$\S \quad$ Forest products sales depot establishment and management in each VDCs as far as possible. For this coordination among district forest product supply board, community forest user groups and CFM groups is necessary to distribute forest products in the district in a systematic and coordinated way.

$\S \quad$ Enhancing good governance through public hearing, public auditing and institutional strengthening.

\section{Conclusion and recommendations}

CFM in Nepal is still in its initial stage. Based on experiences so far CFM can be further improved and made more acceptable to all concerned stakeholders as an appropriate forest management modality promoting active management of productive Terai forests. CFM 
can also harness the opportunities for poverty reduction through income from the forest and wider participation of forestry dependant population in the decision making processes.

For the successful implementation of CFM, following recommendations as way forward are proposed:

Policy and legal aspects: there should be a provision of collaborative forest management in Forest Act. Also, present benefit sharing mechanism among collaborator be revised. Power should be delegated to Regional Forest Director for approval of DFSP, constitution of CFM Groups and CFM Schemes.

Implementation aspects: forest dependent poor people should be brought under mainstreaming providing livelihood alternatives. Specific income generating activities must be implemented focusing poor, women, dalit, janajati and disadvantaged groups for this purpose. CFM committee must have good coordination and linkages with line agencies (esp. DFCC, DFO, etc.) and other service providers. Integrated activities should be implemented. Private and public land forestry activities promoted focusing distant users. As NTFPs could be grown under a short period as compared to trees, it should be promoted inside forest and cultivated in private and public lands.

Activities related to capacity building and institutional strengthening should be implemented to empower poor, women, dalit, janajati and disadvantaged groups. Integrated activities should be implemented coordinating with district level line agencies like DFO, Agriculture, Livestock, Women Development and Soil Conservation Offices.

\section{$\underline{\text { References }}$}

CFM-Working Group of FSCC, 2003. Framework for Collaborative Forest Management in Nepal. Ministry of Forest and Soil Conservation, Kathmandu, Nepal

Ebregt, A.; Paudyal, D.; Siwakoti, R.S.; Sah, R.N.; Thapa, Y.B., 2007. Collaborative Forest Management in Nepal (Challenges and Prospects). Ministry of Forest and Soil Conservation, BISEP-ST, Central Support Unit, Kathmandu, Nepal

MFSC, 2000. Revised Forest Policy 2000. Ministry of Forest and Soil Conservation, Kathmandu, Nepal

Paudyal, D.; Ebregt, A., 2007. Pro-poor leasehold forestry in Nepal: From policy to practice. Ministry of Forest and Soil Conservation, BISEP-ST, Central Support Unit, Kathmandu, Nepal.

Annex 1: Existing and potential CFM areas at BISEP-ST

\begin{tabular}{|c|c|c|c|c|c|}
\hline District & $\begin{array}{l}\text { Name of } \\
\text { CFM Group }\end{array}$ & $\begin{array}{l}\text { Forest } \\
\text { Area (ha) }\end{array}$ & $\begin{array}{l}\text { Total } \\
\text { VDCs/muni. } \\
\text { Covered }\end{array}$ & $\begin{array}{l}\text { Total } \\
\text { households } \\
\text { involved }\end{array}$ & $\begin{array}{l}\text { Status of CFM } \\
\text { scheme approval }\end{array}$ \\
\hline \multirow[t]{3}{*}{ Bara } & Sahajnath & 2058 & 26 & 17527 & Approved \\
\hline & Halkhoria & 1938.5 & $25 / 1$ & 27108 & Proposed (Approved by DFCC) \\
\hline & Tamagadhi & 2500 & 23 & 18032 & Potential, mentioned in DFSP \\
\hline \multirow[t]{3}{*}{ Parsa } & Sabaiya & 3138.5 & $15 / 1$ & 33097 & Approved \\
\hline & Badnihar & 3500 & 15 & 28500 & Proposed \\
\hline & Rangapur & 2000 & 17 & 31000 & Potential, mentioned in DFSP \\
\hline \multirow{2}{*}{ Rautahat } & Rangapur & 1472 & $21 / 1$ & 27014 & Approved \\
\hline & Brindaban & 3200 & 25 & 31250 & Potential, mentioned in DFSP \\
\hline \multirow[t]{3}{*}{ Sarlahi } & Fuljor Baba & 2300 & 22 & 28860 & Proposed \\
\hline & Janakinagar Murtiya & 1700 & 34 & 31214 & Proposed \\
\hline & Lalbandi & 1700 & $35 / 1$ & 30700 & Potential \\
\hline \multirow[t]{3}{*}{ Mahottari } & Banke Maraha & 2006 & 18 & 13522 & Proposed (Approved by DFCC) \\
\hline & Bardibas Gadhanta & 900 & 13 & 14700 & Potential \\
\hline & Tuteshwor Nath & 900 & 11 & 13500 & Potential \\
\hline $\begin{array}{l}\text { Total (up } \\
\text { to July } \\
\text { 2007) }\end{array}$ & $\begin{array}{l}\text { CFM Groups: } \\
14 \text { (in } 5 \text { districts) }\end{array}$ & 29313 & $300 / 4$ & 350024 & \\
\hline Note: & $\begin{array}{l}\text { proved: CFM Sch } \\
\text { posed: Proposed } \\
\text { ential: Included in }\end{array}$ & rict Fol & $\begin{array}{l}\text { DFCC and } \\
\text { led by DFCC } \\
\text { Sector Plan }\end{array}$ & $\begin{array}{l}\text { istry of Fc } \\
\text { r CFM sc }\end{array}$ & $\begin{array}{l}\text { sts and Soil Conservation } \\
\text { me under process of approval) }\end{array}$ \\
\hline
\end{tabular}

The Initiation 2007 


\begin{tabular}{|c|c|}
\hline Institution & Tasks and responsibilities \\
\hline $\begin{array}{l}\text { Ministry of Forest \& } \\
\text { Soil Conservation }\end{array}$ & $\begin{array}{l}\text { Approval of District Forestry Sector Plan (DFSP), but preferably to be } \\
\text { delegated to the DFCC } \\
\text { Approval CFM Scheme, but preferably to be delegated to the DFCC } \\
\text {. Development and implementation of CFM related guidelines and policies } \\
\text {. Coordination with donor organisations } \\
\text { Monitoring and evaluation of CFM }\end{array}$ \\
\hline Department of Forest & $\begin{array}{l}\text { Recommend ministry for approval of District Forestry Sector Plan } \\
\text { Support implementation of policy, guidelines and plan } \\
\text { Monitoring and evaluation of CFM }\end{array}$ \\
\hline $\begin{array}{l}\text { Regional Forest } \\
\text { Directorate }\end{array}$ & $\begin{array}{l}\text { Support planning, policy formulation, coordination and capacity building } \\
\text { Monitoring and evaluation }\end{array}$ \\
\hline District Forest Office & $\begin{array}{ll} & \text { Support preparation of CFM Scheme and DFSP. Sign management } \\
\text { agreement with CFM Committee } \\
\text { Facilitate CFM Scheme implementation } \\
\text { Information communication and extension } \\
\text { Monitor CFM-scheme implementation and reporting to DFCC, RD and . } \\
\text { Department of Forests }\end{array}$ \\
\hline$\overline{\mathrm{DDC}}$ & $\begin{array}{l}\text { Coordination for implementation of Community Forestry, Collaborative } \\
\text { Forest Management and other participatory forest management modalities } \\
\text { Support for management of necessary resources to prepare and implement } \\
\text { forest management plans } \\
\text { Coordinating VDC/Municipality and DDC members to identify boundaries } \\
\text { of different participatory forest management areas and conflict management } \\
\text { Endorsement of yearly forestry programmes (as per approved management } \\
\text { plans) } \\
\text { Monitoring and evaluation of CFM }\end{array}$ \\
\hline \multirow[t]{2}{*}{ DFCC } & $\begin{array}{l}\text { Roles and responsibilities of DFCC are mentioned on DFCC Guideline } 2062 . \\
\text { In CFM its major roles and responsibilities are: }\end{array}$ \\
\hline & $\begin{array}{l}\text { Support formulating district level strategy and programme related to forestry } \\
\text { Delineating CFM area and its users location (social unit) } \\
\text { Endorsement of DFSP and CFM Scheme } \\
\text { Management of District Forest Development Fund for implementing DFSP } \\
\text { Identification of stakeholders, their roles and coordinate them in order to } \\
\text { manage conflicts } \\
\text { Fixing price of forest products to be sold among users and facilitate and } \\
\text { coordinate supply of forest products } \\
\text { Selection of auditor } \\
\text { Selection of DDC member and other representatives (as per CFM guidelines) } \\
\text { to represent CFM Group } \\
\text { Monitoring, public auditing, follow-up and evaluate CFM Scheme } \\
\text { implementation }\end{array}$ \\
\hline VDC and Municipality & $\begin{array}{l}\text { Planning and scoping of VDC/Municipality level forest development activities } \\
\text { Support selection of ward representatives including women, Dalit, Adibasi } \\
\text { Janajati for CFM Group formation, } \\
\text { Support supply of forest products and depot management for forest users } \\
\text { Identification of stakeholders and their roles, coordinate for managing } \\
\text { conflicts } \\
\text { Support leasing public lands and land under public institutions for poor } \\
\text { groups to develop agro-forestry and IGA activities } \\
\text { Monitoring of VDC/Municipality level forest development activities }\end{array}$ \\
\hline CFM-Group & $\begin{array}{l}\text { These are members with the following tasks: } \\
\text { Elect CFM Committee members } \\
\text {. Advise and approve long term policies, strategies and management plan } \\
\text { for the CFM } \\
\text {. Approve the annual financial and audit report } \\
\text {. Approve the annual work plan and investment scheme } \\
\text { Propose and approve revenues sharing and development project proposals }\end{array}$ \\
\hline
\end{tabular}




\begin{tabular}{ll}
\hline CFM-Committee & This is the executive committee with as tasks: \\
& Advise on policy and finalisation proposals \\
& Selection and recruitment of staff for CFM Implementation Unit \\
& Control of the CFM Implementation Unit \\
$\cdot$ & Endorsement of management plan, annual work plan and annual financial \\
& and audit report \\
$\cdot$ & Responsible for the CFM Account \\
$\cdot$ & Prepare revenues sharing and development proposals \\
$\cdot$ & Implementation of decisions taken by the CFM Group \\
& Networking with the civil society
\end{tabular}

CFM-Implementation The CFM Implementation Unit is the executive body of the CFM Committee. Unit

This unit is responsible for:

Daily management and implementation of the CFM Scheme

Preparation of annual work plan and investment plan

Assist in the preparation of policies and management plan

Administration and finances

Sale of timber, procurement of seedlings, application of subsidies etc.

Preparation of CFM-Committee and General Assembly meetings.

Forest users . Support for CFM Scheme preparation and implementation

(close and distant) . Ward level user representative selection as CFM Group member

Contribution to forest protection and management

Follow the CFM Group and committee decisions

Support formation of different sub-committees

Participate on public audit and public hearing to enhance good forest governance

Stakeholders

In addition to collaborators mentioned above, the following stakeholders have some roles and responsibilities for forest protection and development:

In general stakeholders have to support implementation of policy, strategy, programmes as formulated. Specific roles are:

NGOs:

Support capacity building of forest users; facilitate implementation of programmes

Support identification of target groups and their settlements

Coordination with VDC/Municipality/DDC and other line agencies Support public auditing, public hearing and advocacy

Political Parties:

Extension of programme, support group formation and programme selection Lobbying and advocacy for improvement of programme and implementation

Civil Society:

Extension of programme like CF, CFM, pro-poor leasehold forestry, private forestry and public land forestry

Critical analysis of activities implemented; support control of smuggling of forest products

Participation on public audit and public hearing

Adapted from Ebregt et al., 2007; CFM Guideline (proposed amendment) 2064

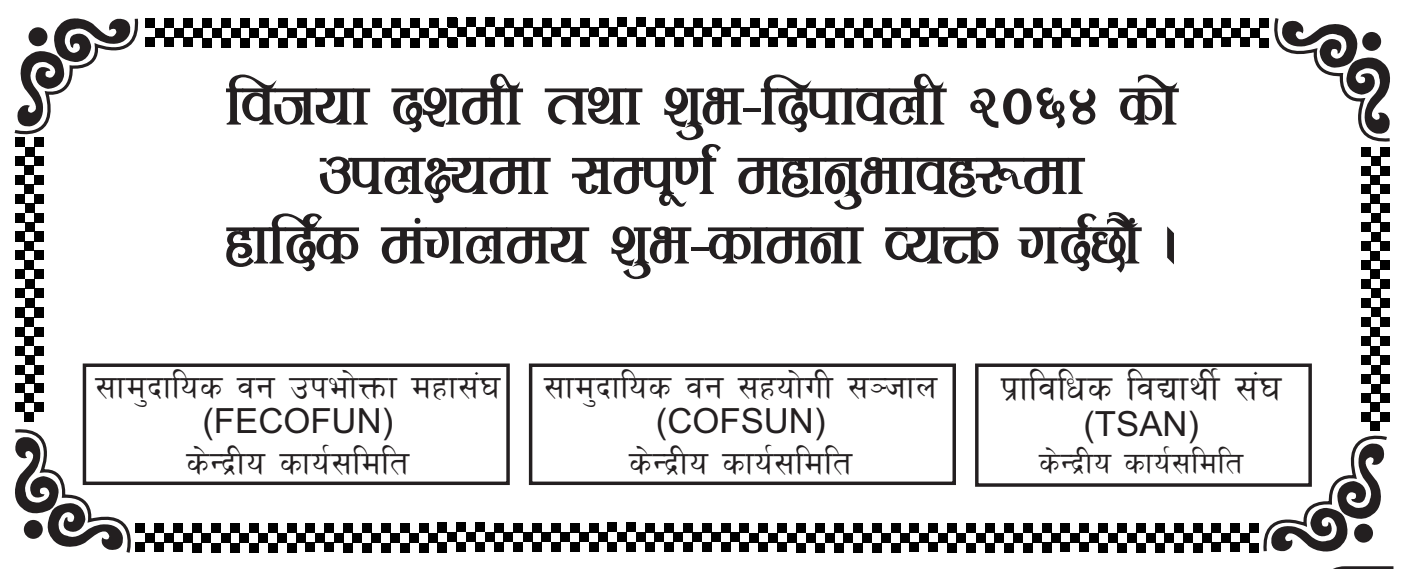

The Initiation 2007071 